\title{
Degradation of Bacteria by Agaricus bisporus and Other Fungi
}

\author{
By T. R. FERMOR* AND D. A. WOOD \\ Glasshouse Crops Research Institute, Rustington, Littlehampton, West Sussex BN16 3 PU, \\ U.K.
}

(Received 16 February 1981; revised 30 March 1981)

\begin{abstract}
Agaricus bisporus and other fungi (Basidiomycetes, Ascomycetes, Fungi Imperfecti and Phycomycetes) grew and produced transparent zones in opaque media containing killed Bacillus subtilis as sole carbon and nitrogen source. Other Gram-positive and Gram-negative bacteria were also degraded by $A$. bisporus. Degradation of $B$. subtilis by $A$. bisporus was examined by light and electron microscopy. Liquid cultures were assayed for extracellular fungal enzymes which included $\beta$ - $N$-acetylglucosaminidase, lipase, nucleases and acid, neutral and alkaline proteases.

Microbial biomass in compost may serve as a source of nitrogen, carbon and minerals, and as a water reserve for the growth of $A$. bisporus.
\end{abstract}

\section{INTRODUCTION}

The substrate for growth and fruiting of Agaricus bisporus in commerce is prepared by the composting of wheat straw. During this process a defined microbial succession occurs and large numbers of micro-organisms are produced, as shown by plate counts (Fermor et al., 1979; Fermor \& Wood, 1979). This accumulated microbial biomass could serve as a major source of nitrogen for the mycelium of the fungus. Micro-organisms could serve also as a source of carbon compounds and a mineral source, as well as a water reserve for the growing mycelium. Recent studies following the recognition of the role of organisms in carbon, nitrogen and phosphorus flows in nature have stressed the role of micro-organisms as sources and sinks for nutrients, in addition to their traditional role in the transformation of nutrient elements (Paul \& Voroney, 1980). Many classes of organisms possess bacteriolytic enzymes (Stolp \& Starr, 1965; Strominger \& Ghuysen. 1967; Gooday, 1979) some of which have been shown to have a nutritional role.

This present investigation had two aims; firstly, to study whether degradation of dead bacteria was a possible mode of nutrition for filamentous fungi, and in particular whether it was used by $A$. bisporus, and secondly, to determine the nature of the extracellular enzymes produced by $A$. bisporus which might be used to degrade bacteria. Bacillus subtilis was chosen as the main subject of these experiments because it was the bacterium most frequently isolated from mushroom composts and is also very common in soil.

\section{METHODS}

Organisms. Agaricus bisporus D621 was used. This is a heterokaryotic fertile strain of commercial origin. Basidiomycete cultures were obtained from the Glasshouse Crops Research Institute collection of fungi. Phycomyces blakesleeanus, Sordaria fimicola and Neurospora tetrasperma were the gift of $\mathrm{Dr} \mathrm{C}$. Thurston, Queen Elizabeth College, London. Bacillus subtilis 168 derivative S2861 (trivial name 261) spoIIA69 spoG55 rif-2 (asporogenous) was the gift of Dr P. J. Piggot, National Institute for Medical Research, London. Other bacteria were obtained from the National Collection of Type Cultures, London. All other organisms used in the present study were isolated directly from mushroom compost. 
Fungal media and culture. Basal salts medium (Treschow, 1944) was used as the standard medium in all experiments. The composition of this medium is: $\mathrm{KCl}, 0.2 \mathrm{~g} ; \mathrm{MgSO}_{4} .7 \mathrm{H}_{2} \mathrm{O}, 0.2 \mathrm{~g} ; \mathrm{CaCl}_{2}, 0.2 \mathrm{~g} ; \mathrm{FeCl}_{3} .6 \mathrm{H}_{2} \mathrm{O}$, $10 \mathrm{mg} ; \mathrm{Na}_{2} \mathrm{HPO}_{4} .2 \mathrm{H}_{2} \mathrm{O}$ (stock solution $15 \mathrm{~g} \mathrm{l}^{-1}$ ), $75 \mathrm{ml} ; \mathrm{KH}_{2} \mathrm{PO}_{4}$ (stock solution $9 \mathrm{~g} \mathrm{l}^{-1}$ ), $15 \mathrm{ml}$; vitamin solution ( $20 \mathrm{mg}$ thiamin. $\mathrm{HCl}$ and $2 \mathrm{mg}$ biotin in $100 \mathrm{ml}$ distilled water), $1 \mathrm{ml} ; \mathrm{H}_{3} \mathrm{BO}_{3}, 0.3 \mathrm{mg} ; \mathrm{CuSO}_{4} .5 \mathrm{H}_{2} \mathrm{O}, 0.25 \mathrm{mg}$; $\mathrm{MnCl}_{2} .4 \mathrm{H}_{2} \mathrm{O}, 2 \mathrm{mg} ; \mathrm{Na}_{2} \mathrm{MoO}_{4} .7 \mathrm{H}_{2} \mathrm{O}, 0.4 \mathrm{mg} ; \mathrm{ZnSO}_{4} .7 \mathrm{H}_{2} \mathrm{O}, 0.2 \mathrm{mg} ; \mathrm{CoCl}_{2} .6 \mathrm{H}_{2} \mathrm{O}, 0.7 \mathrm{mg}$; distilled water to 1 litre. The stock solutions were each sterilized and added to the medium after autoclaving.

For determining growth of $A$. bisporus on a range of Gram-positive and Gram-negative bacteria, bacteria were grown as shake cultures $(600 \mathrm{ml})$ in nutrient broth (Oxoid) and harvested at the end of the exponential phase of growth. Bacterial cultures were centrifuged $(15000 \mathrm{~g}, 10 \mathrm{~min})$ then rinsed in distilled water. These cells were added to $200 \mathrm{ml}$ medium which contained either Eggins \& Pugh salts + yeast extract (Eggins \& Pugh, 1962) or basal salts (Treschow, 1944), and $3 \mathrm{~g}$ agar (Difco Bacto), and autoclaved (103 kPa, $20 \mathrm{~min}$ ). Standard volume (20 $\mathrm{ml})$ plates were poured, inoculated with mycelial discs (4 mm diam.) of $A$. bisporus D621 and incubated at $25^{\circ} \mathrm{C}$.

Degradation of $B$. subtilis by filamentous fungi was indicated by the production of transparent zones in the opaque Treschow basal salts medium containing suspended bacteria. The medium was prepared in individual bottles each containing: Treschow basal salts, $20 \mathrm{ml}$; Ion agar no. 2 (Oxoid), $500 \mathrm{mg}$; freeze-dried B. subtilis, $400 \mathrm{mg}$. The following were added separately to each bottle after autoclaving ( $103 \mathrm{kPa}, 20 \mathrm{~min}$ ) from sterile stock solutions: $\mathrm{Na}_{2} \mathrm{HPO}_{4} .2 \mathrm{H}_{2} \mathrm{O}\left(15 \mathrm{~g} \mathrm{l}^{-1}\right), 4.9 \mathrm{ml} ; \mathrm{KH}_{2} \mathrm{PO}_{4}\left(9 \mathrm{~g} \mathrm{l}^{-1}\right), 0.1 \mathrm{ml}$; vitamin solution $(20 \mathrm{mg}$ thiamin. $\mathrm{HCl}$ and $2 \mathrm{mg}$ biotin in $100 \mathrm{ml}$ distilled water), $0.1 \mathrm{ml}$. When the medium ( $\mathrm{pH} \mathrm{5.7)} \mathrm{had} \mathrm{solidified,} \mathrm{it} \mathrm{was} \mathrm{inoculated} \mathrm{with}$ mycelial discs (4 mm diam.) of filamentous fungi and incubated at $25^{\circ} \mathrm{C}$.

Medium of similar composition, without agar, but with $500 \mathrm{mg}$ bacteria was used in static liquid cultures ( $25 \mathrm{ml}$ medium per $250 \mathrm{ml}$ flask) to study extracellular enzyme production and dry weight loss and to provide samples for electron microscopy. Each flask of medium was inoculated with a vegetative mycelial suspension of $A$. bisporus $(0.1 \mathrm{ml})$ and incubated at $25^{\circ} \mathrm{C}$. The inocula were prepared as follows. The fungus was grown in three flasks ( $250 \mathrm{ml}$ capacity with $25 \mathrm{ml}$ liquid malt extract at $20 \mathrm{~g}^{-1}$ ) for 4 weeks at $25^{\circ} \mathrm{C}$. Cultures were then centrifuged $(10000 \mathrm{~g}, 30 \mathrm{~min})$, the supernatant was decanted, the mycelium was rinsed and then added to sterile distilled water $(100 \mathrm{ml})$. The mycelial suspension was shaken with approximately 100 glass beads $\left(5 \mathrm{~mm}\right.$ diam.; 400 rev. $\mathrm{min}^{-1}$, $30 \mathrm{~min}$ ).

Bulk culture of bacteria. For determination of fungal growth (other than A. bisporus) on solid media, and for determination of $A$. bisporus growth in liquid media, large-scale cultures of $B$. subtilis 168 (asporogenous) were grown. For this, the bacteria were first subcultured in nutrient broth (Oxoid) followed by growth on nutrient agar at $30^{\circ} \mathrm{C}$. Cells then grown in shaken culture in Spizizen salts medium (S.S.M.; Piggot, 1975) to check culture purity and growth characteristics. S.S.M. contained (in $900 \mathrm{ml}$ ): $\left(\mathrm{NH}_{4}\right)_{2} \mathrm{SO}_{4}, 2 \mathrm{~g} ; \mathrm{K}_{2} \mathrm{HPO}_{4}, 14 \mathrm{~g} ; \mathrm{KH}_{2} \mathrm{PO}_{4}, 6 \mathrm{~g}$; trisodium citrate. $2 \mathrm{H}_{2} \mathrm{O}, 1 \mathrm{~g} ; \mathrm{MgSO}_{4} \cdot 7 \mathrm{H}_{2} \mathrm{O}, 0.2 \mathrm{~g}$. The final medium consisted of: S.S.M., $900 \mathrm{ml}$; monosodium glutamate $\left(15 \mathrm{~g} \mathrm{l}^{-1}\right.$, adjusted to $\mathrm{pH} 7.0$ with $\left.\mathrm{NaOH}\right), 90 \mathrm{ml}$; glucose $\left(200 \mathrm{~g} \mathrm{l}^{-1}\right), 10 \mathrm{ml}$. The components were sterilized separately by autoclaving. All chemicals used were laboratory grade (BDH). These small shake-flask cultures were used to inoculate 201 fermenter cultures which were, in turn, used to seed four 4001 cultures in S.S.M. The cultures were incubated at $30^{\circ} \mathrm{C}$, and harvested at the end of the exponential phase of growth. The harvested cells were treated as follows: (i) suspended in trichloroacetic acid $\left(100 \mathrm{~g}^{-1}\right)$ for $2 \mathrm{~h}$ at room temperature; (ii) centrifuged $(5000 \mathrm{~g}, 20 \mathrm{~min}$ ) to remove most of the trichloroacetic acid; (iii) washed three times in copious distilled water to about $\mathrm{pH} 4.0$ (continuous centrifuging M.S.E. 18 at $15000 \mathrm{~g}$ ); (iv) extracted with an equal volume of ether, twice, to remove soluble cell contents and residual trichloroacetic acid; (v) freeze-dried.

Enzyme assays. Assays were performed on liquid culture supernatants obtained after centrifugation $(18000 \mathrm{~g}, 30 \mathrm{~min})$. Supernatants were stored at $-20^{\circ} \mathrm{C}$ until required; freezing and thawing did not affect enzyme activity. Laccase was assayed polarographically (Wood \& Goodenough, 1977). Tyrosinase was assayed using a method similar to that for laccase but substituting 3,4-dihydroxyphenylalanine as substrate. One unit of laccase or tyrosinase was defined as that amount of enzyme catalysing the consumption of $1 \mu \mathrm{mol} \mathrm{O}_{2} \mathrm{~min}^{-1}$. Acid, neutral and alkaline proteases were measured colorimetrically by the liberation of dye from an insoluble substrate, Remazol Brilliant Blue-hide powder conjugate (Rinderknect et al., 1968). The incubation mixture, which contained $12 \mathrm{mg}$ substrate, $0.6 \mathrm{ml}$ supernatant and $1.2 \mathrm{ml}$ buffer, was incubated at $25^{\circ} \mathrm{C}$ and the reaction was terminated by the addition of trichloroacetic acid $\left(500 \mathrm{~g} \mathrm{l}^{-1}\right)$. After centrifugation $(10000 \mathrm{~g}, 10 \mathrm{~min})$ the absorbance was measured spectrophotometrically at $595 \mathrm{~nm}$. Activity was calculated as $\mu \mathrm{g}$ Remazol Brilliant Blue (RBB) solubilized $\mathrm{h}^{-1}(\mathrm{ml} \text { extract) })^{-1}$ at $25^{\circ} \mathrm{C}$. $\beta$-N-Acetylglucosaminidase assay with a $p$-nitrophenyl glycoside as substrate was carried out as follows. Culture supernatant $(0.2 \mathrm{ml})$ was added to a solution $(0.4 \mathrm{ml})$ of $p$-nitrophenyl- $N$-acetyl- $\beta$-D-glucosaminide (Sigma, $1 \mathrm{mg} \mathrm{ml}^{-1}$ ) in $0.05 \mathrm{M}$-acetate buffer $(\mathrm{pH} 5.0$ ) and incubated at $25^{\circ} \mathrm{C}$ for $1 \mathrm{~h}$. The reaction was terminated by the addition of $1 \mathrm{M}-\mathrm{Na}_{2} \mathrm{CO}_{3}(2 \mathrm{ml})$; the released $p$-nitrophenol was measured spectrophotometrically at $400 \mathrm{~nm}$. Activity was calculated as $\mu \mathrm{mol} p$-nitrophenol released $\mathrm{min}^{-1}(\mathrm{ml}$ culture supernatant $)^{-1}$. Lysozyme was assayed by measuring the decrease in turbidity of a suspension of Micrococcus lysodeikticus (Sigma) at $540 \mathrm{~nm}$ (Demetriou et al., 1974).

The medium described by Sierra (1957) was used in a preliminary experiment to detect whether $A$. bisporus produced lipase in solid medium; sorbitan monolaurate (Tween 20) was used as the lipid substrate. Later, the 
lipase activity of liquid culture supernatant was assayed using a modification of an agar diffusion method (Lawrence et al., 1967). An emulsion of tributyrin $\left(0.5 \mathrm{ml}, 10 \mathrm{ml} 1^{-1}\right)$ in water (prepared by sonication, $1.5 \mathrm{~A}$ for $5 \mathrm{~min}$ ) was added to $4.5 \mathrm{ml}$ of a hot solution of agar (Oxoid Ion agar no. $2,11.1 \mathrm{~g} \mathrm{I}^{-1}$ in $0.05 \mathrm{M}$-phosphate buffer, $\mathrm{pH} 7.0)$. This emulsion $(5 \mathrm{ml})$ was spread evenly over a microscope slide $(3.75 \times 7.5 \mathrm{~cm})$, four holes $(6 \mathrm{~mm}$ diam.) were made with a steel cutter and $20 \mu \mathrm{l}$ supernatant was added to each. The slide was placed in a humid chamber and incubated at $25^{\circ} \mathrm{C}$ for $65 \mathrm{~h}$, prior to measuring the diameter of cleared zones formed in the opaque medium.

The agar diffusion technique (Lawrence et al.. 1967) was used to detect DNAase and RNAase. DNA (calf thymus, Sigma; $1 \mathrm{mg} \mathrm{ml}^{-1}$ ) or yeast RNA (BDH: $2 \mathrm{mg} \mathrm{ml}^{-1}$ ) was suspended in the agar medium in $0.1 \mathrm{M}$-acetate buffer ( $\mathrm{pH} 5 \cdot 0$ ). To each well was added $20 \mu$ culture supernatant, the slides were placed in humid chambers and incubated at $25^{\circ} \mathrm{C}$. After 2 to $3 \mathrm{~d}$, slides were flooded with $1 \mathrm{M}-\mathrm{HCl}$ and clear zones in the opaque medium indicated areas of nuclease activity. As nuclease activity was found to be very low, supernatants were concentrated (15- to 20-fold) by ultrafiltration over a PM10 membrane (Amicon). Supernatants for nuclease assay were taken from cultures in which the phosphate buffer had been replaced by $0.1 \mathrm{M}$-Tris (the initial $\mathrm{pH}$ of the medium was 5.5), as no nuclease activity could be detected in supernatants of cultures in the standard media (on which all the other enzyme assays were performed).

Electron microscopy. Samples of bacteria and bacteria/fungal mycelial mats were taken from liquid cultures and fixed in Karnovsky's fixative for $2 \mathrm{~h}$ (Karnovsky, 1965), followed by four 30 min washes in $0.2 \mathrm{M}$-cacodylate buffer ( $\mathrm{pH}$ 7.4). Post-fixation in $\mathrm{OsO}_{4}\left(20 \mathrm{~g}^{-1}\right)$ was followed by a further four washes in cacodylate buffer. Dehydration by passage through graded water/ethanol mixtures was followed by embedding in Spurr's resin (Spurr, 1969). Sections were post-stained with uranyl acetate $\left(20 \mathrm{~g}^{-1}\right)$ for $1 \mathrm{~h}$ and with lead citrate for $30 \mathrm{~min}$ (Reynolds, 1963) prior to examination.

\section{RESULTS}

\section{Growth of $A$. bisporus on bacteria}

Agaricus bisporus produced transparent zones in the opaque medium (cleared zones) when grown on media containing autoclaved suspensions of Gram-positive or Gram-negative bacteria (Table 1). The distance of the cleared zones in advance of the growing mycelial front could be increased by incubating the plates in a refrigerator, which slowed hyphal growth whilst allowing extracellular enzymes to diffuse through the media. Sections of agar gel taken from cleared and non-cleared areas were stained and examined by light microscopy. These showed the absence of bacteria in the cleared area (Fig. 1). Colony radial growth rates of $A$. bisporus were $30-60 \%$ slower on media containing suspended bacteria than on malt extract agar $\left(20 \mathrm{~g}^{-1}\right)$, but the hyphae grew more closely. Growth rates of $A$. bisporus were slightly greater on Eggins \& Pugh medium (containing carbon and nitrogen sources) than on Treschow basal salts (containing autoclaved bacteria as the sole source of carbon and nitrogen) when both media contained the same species of autoclaved bacteria in suspension.

\section{Growth of fungi on B. subtilis}

The majority of the filamentous fungi successfully colonized and degraded B. subtilis in solid medium (Table 2). None of the Agaricus spp. nor other Basidiomycetes formed fruit-body primordia on this medium in which the bacteria were the sole source of carbon and nitrogen. The ability to utilize dead B. subtilis was not restricted to the Basidiomycetes; representatives from the Ascomycetes, Fungi Imperfecti and Phycomycetes were also able to use this mode of nutrition (Table 2). Basidiomycetes grew at approximately half of their normal growth rate on a standard fungal medium, whereas the other classes of fungi grew 5to 10 -fold slower. The morphology of the Fungi Imperfecti was atypical of that normally found on standard fungal media: Aspergillus fumigatus sporulated, but the colony colour was grey; Penicillium sp., normally blue-green on malt extract agar, grew as a non-sporulating white mycelial colony; Trichoderma viride, normally a fast-growing green colony, sporulated but formed an extremely slow-growing velvety-beige colony having distorted hyphae. 
Table 1. Growth of Agaricus bisporus on autoclaved bacteria suspended in solid media

$$
\text { Bacterial species }
$$

Acinetobacter calcoaceticus NCTC 7844

Acinetobacter calcoaceticus NCTC 7844

Alcaligenes faecalis NCTC 655

Bacillus subtilis*

Bacillus subtilis 168 , wild type

Bacillus subtilis 168, asporogenous

Bacillus coagulans*

Bacillus stearothermophilus*

Bacillus stearothermophilus*

Klebsiella pneumoniae NCTC 418

Klebsiella pneumoniae NCTC 418

Mycobacterium phlei NCTC 8151

Proteus vulgaris NCTC 4175

Staphylococcus epidermidis NCTC 4276

(Micrococcus sp. subgroup 1)

Staphylococcus epidermidis NCTC 4276

(Micrococcus sp. subgroup 1)

Escherichia coli NCTC 9001

Control

Control

Control

$\begin{array}{clcc}\begin{array}{c}\text { Gram } \\ \text { reaction }\end{array} & \text { Medium }{ }^{-} & \begin{array}{c}\text { Colony radial } \\ \text { extension rate } \\ \left(\mathrm{mm} \mathrm{d}^{-1}\right)\end{array} & \begin{array}{c}\text { Cleared } \\ \text { zone }\end{array} \\ - & \text { EP } & 1.14 & + \\ - & \text { TBS } & 1.01 & + \\ - & \text { TBS } & 0.90 & + \\ + & \text { EP } & 0.80 & + \\ + & \text { EP } & 0.76 & + \\ + & \text { TBS } & 0.91 & + \\ + & \text { EP } & 0.61 & + \\ + & \text { EP } & 0.98 & + \\ + & \text { TBS } & 0.91 & + \\ - & \text { EP } & 0.92 & + \\ - & \text { TBS } & 0.84 & + \\ \text { var. } & \text { EP } & 0.68 & + \\ - & \text { EP } & \text { ND } & + \\ + & \text { EP } & \text { ND } & - \\ + & \text { TBS } & \text { ND } & - \\ + & \text { EP } & \text { ND } & + \\ - & \text { ME } & 1.55 & - \\ & \text { EP(G) } & 1.05 & - \\ & \text { TBS } & \text { NG } & -\end{array}$

* Isolated from compost. $1^{-1}$.

† EP, Eggins \& Pugh; TBS, Treschow basal salts; ME, malt extract; EP(G), Eggins \& Pugh with 10 g glucose

\section{Liquid cultures and electron microscopy}

Bacillus subtilis cells were harvested in the late-exponential phase of growth. The fixation and staining procedures used to examine them were shown not to cause cell wall degradation (Fig. 2a), though there was a small number (1-2\%) of lysed cells in these preparations. However, the cells were distorted by freeze drying (Fig. $2 b$ ) and needed a period of rehydration before most of them resumed normal cell shapes. Mycelium of $A$. bisporus degraded these $B$. subtilis cells (when used as sole carbon and nitrogen source) in liquid media (Fig. $2 c, d$ ). Examination with the microscope (after $35 \mathrm{~d}$ ) revealed several changes in the bacteria from such cultures: bacterial counts were smaller; bacteria were less clumped; cell contents had considerably shrunk or disappeared; cell walls were perforated and wall fragments were apparent; wall thickness was substantially reduced in some bacteria.

Increase in laccase activity, used to estimate $A$. bisporus mycelial growth, was found roughly to correspond with the total dry weight loss in the cultures (Fig. 3), and both followed the pattern expected for $A$. bisporus growth in liquid culture. The $\mathrm{pH}$ of the medium showed a large shift from acid to alkaline. Between $14 \mathrm{~d}$ after inoculation and the end of the experiments the cultures progressively changed from colourless to dark brown.

Liquid cultures were assayed for the pattern of extracellular enzyme activities (Table 3 ). $\beta$ - $N$-Acetylglucosaminidase activity was found (Fig. $4 a$ ). The enzyme was active over a wide range from $\mathrm{pH} 2 \cdot 8$ to $8 \cdot 0$. $\beta$-N-Acetylglucosaminidase activity appeared to be induced by the presence of the bacteria in the liquid cultures. No enzyme activity was detected when $A$. bisporus mycelium was grown in Treschow basal salts medium with glucose and glutamate as the carbon and nitrogen sources instead of bacteria.

Acid, neutral and alkaline proteases were produced by $A$. bisporus (Fig. $4 a$ ). Neutral protease showed the greatest activity reaching a peak between 20 and $40 \mathrm{~d}$. In addition, $A$. bisporus was grown on an insoluble protein source, casein, in Treschow basal salts medium to 

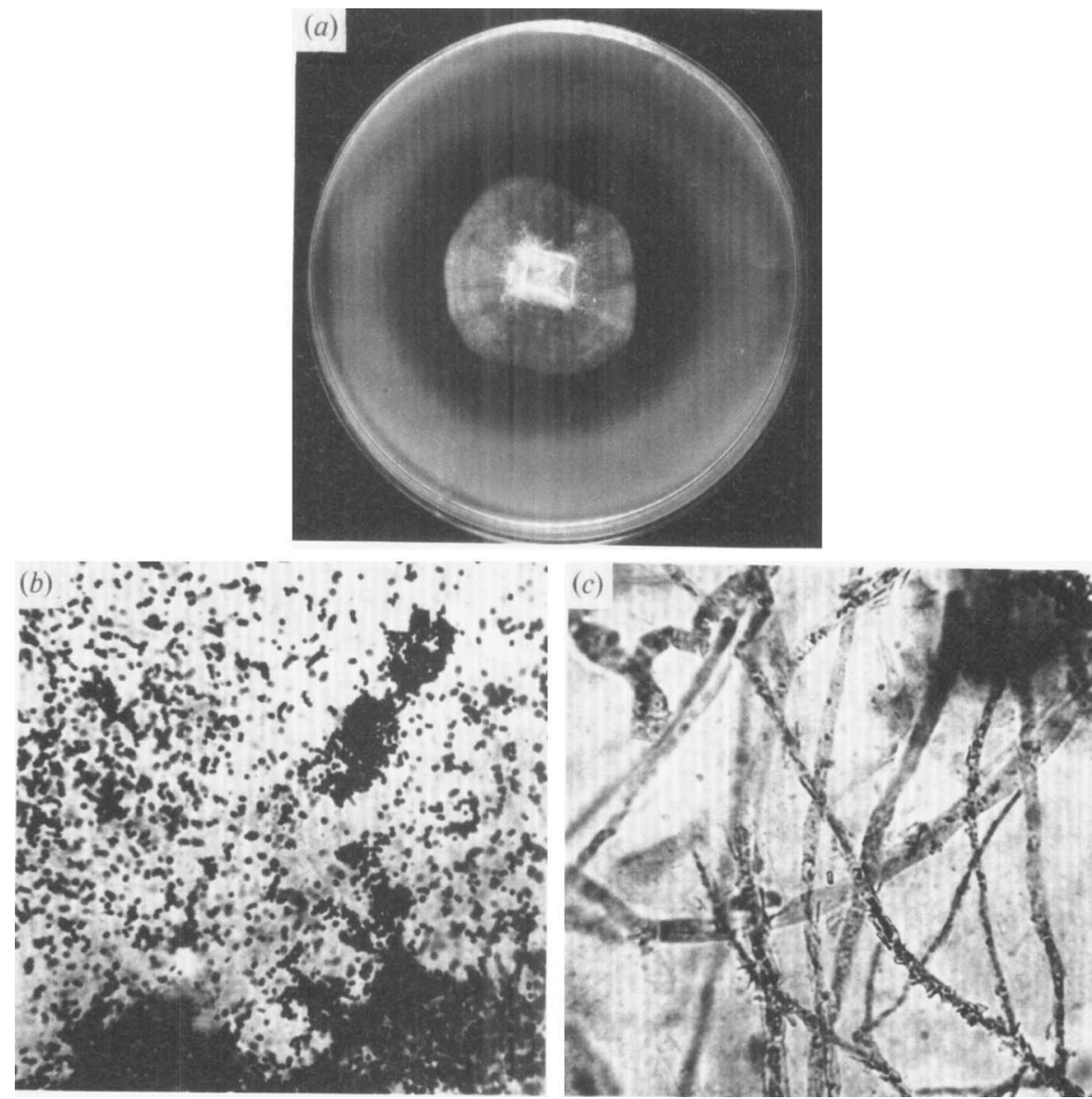

Fig. 1. Growth of $A$. bisporus on Treschow basal salts agar containing autoclaved Gram-negative bacteria (Alcaligenes faecalis) as sole carbon and nitrogen source. (a) Well-defined cleared zone formed in advance of the colonizing mycelium. $(b)$ Uncolonized agar with autoclaved bacteria. (c) Colonized agar (from cleared zone) showing very few bacteria present, thus indicating that the majority of the bacteria originally present had been degraded by extracellular enzymes from $A$. bisporus mycelium.

compare the pattern of extracellular proteases produced. Insoluble casein was degraded faster than bacteria; protease activities were 2- to 3-fold higher. Protease production reached a peak after $15 \mathrm{~d}$ and both neutral and alkaline proteases had high activity (Fig. $4 \mathrm{~b}$ ).

The formation of lipolytic enzymes by a colony of $A$. bisporus was indicated by a whitish cream precipitate in Sierra's medium due to the formation of crystals of the calcium salt of lauric acid released by the enzyme. Lipase activity as assayed by measuring the hydrolysis of an emulsified triglyceride (tributyrin) started after $20 \mathrm{~d}$ and reached a peak at $44 \mathrm{~d}$. The same pattern of activity was found for DNAase and RNAase (when cultures were grown in phosphate-free medium). No tyrosinase or lysozyme activity was detected.

\section{DISCUSSION}

The quantity and turnover rate of microbial biomass accumulated during the preparation and cropping phases of a mushroom compost are unknown. Estimates extrapolated from plate counts and bacterial cell weights indicate that 3-5\% of compost dry weight could be bacterial in origin (Fermor \& Wood, 1979). Some of the techniques currently employed to 
Table 2. Growth of fungi on autoclaved Bacillus subtilis suspended in solid medium, incubated at $25^{\circ} \mathrm{C}$ for $28 \mathrm{~d}$

$\begin{array}{ccc} & \begin{array}{c}\text { Colony radial } \\ \text { extension rate* } \\ \left(\mathrm{mm} \mathrm{d}^{-1}\right)\end{array} & \begin{array}{c}\text { Cleared } \\ \text { Fone }\end{array}\end{array}$

\author{
BASIDIOMYCETES \\ Agaricus bisporus (Lange) Imbach D621 \\ Agaricus bisporus (Lange) Imbach $\mathrm{S} 22$ \\ Agaricus bitorquis (Quél.) Sacc. \\ Agaricus macrosporus (Møll. and Schaff.) Pilàt \\ Agaricus silvicola (Vitt.) Peck \\ Favolus arcularius (Fr.) Ames \\ Flammulina velutipes (Curt. ex Fr.) Karst \\ Pleurotus ostreatus (Jacq. ex Fr.) Kummer \\ Stropharia merdaria $\mathrm{Fr}$. \\ Schizophyllum commune Fr. \\ Volvariella volvacea (Bull. ex Fr.) Sing.
}

\section{ASCOMYCETES}

Chaetomium globosum Kunze

Diehliomyces microsporus (Diehl and Lambert) Gilkey

Neurospora tetrasperma Shear and Dodge

Sordaria fimicola (Roberge) Cesati and de Notaris

\section{FUNGI IMPERFECTI}

Arthrobotrys oligospora Fres.

Aspergillus fumigatus Fres.

Hormiactis alba (Preuss)

Humicola grisea var. thermoidea Cooney and Emerson

Penicillium sp.

Scytalidium thermophilum (Cooney and Emerson) Austwick

Trichoderma viride Pers.

\section{PHYCOMYCETES}

Mucor hiemalis Wehmeyer

Rhizomucor pusillus (Lindt) Schipper

Phycomyces blakesleeanus (+) Burgeff, IMI 118496i

* ND, Not determined; NG, no growth.

$\begin{array}{rr}0.91 & + \\ 0.95 & + \\ 0.87 & + \\ 0.72 & + \\ 0.50 & + \\ 1.42 & + \\ >1.50 & + \\ >1.50 & + \\ 1.28 & + \\ >1.50 & + \\ >1.50 & +\end{array}$

$\begin{array}{cc}1.50 & + \\ \text { NG } & - \\ 1.90 & + \\ 2.22 & -\end{array}$

$\begin{array}{cc}1.27 & + \\ 1.17 & + \\ <0.50 & - \\ >1.50 & + \\ <0.50 & + \\ <0.50 & - \\ 1.15 & + \\ & \\ 1.55 & + \\ \text { ND } & + \\ \text { NG } & +\end{array}$

$\uparrow$ Very limited.

determine microbial biomass in soils or sediments (Domsch et al., 1979; Paul \& Voroney, 1980) are inapplicable to mushroom compost. The measurement of specific cell constituents is invalid because the concentration of these constituents varies according to the proportions of particular organisms in the very heterogeneous population. Techniques which rely on activating a mainly dormant microbial population, such as usually found in soil, and monitoring subsequent metabolic changes have yet to be applied to composts.

There is very little information available on the longevity and fate of bacteria in natural environments. Siala \& Gray (1974) observed growth of $B$. subtilis on microscope slides in soil. Growth occurred for 1 week, with a generation time of $9.5 \mathrm{~d}$. In the subsequent 8 weeks the population declined slowly and approximately half the vegetative propagules became spores while the remainder disappeared. In comparison, bacterial numbers and activity in the first two stages of composting are very high (Fermor et al., 1979; Fermor \& Wood, 1979). After the 'peak-heating' stage of compost preparation when mushroom mycelium is inoculated into the compost, numbers of bacteria fall initially and then remain at a constant level $\left[10^{6}-10^{8} \text { (g dry wt compost }\right)^{-1} ; \mathrm{T}$. R. Fermor, unpublished results] indicating a steady turnover rate.

The population consists of both Gram-positive and Gram-negative bacteria and in the present study $A$. bisporus lysed both. This contrasts with the lytic enzyme Chalaropsis B, 

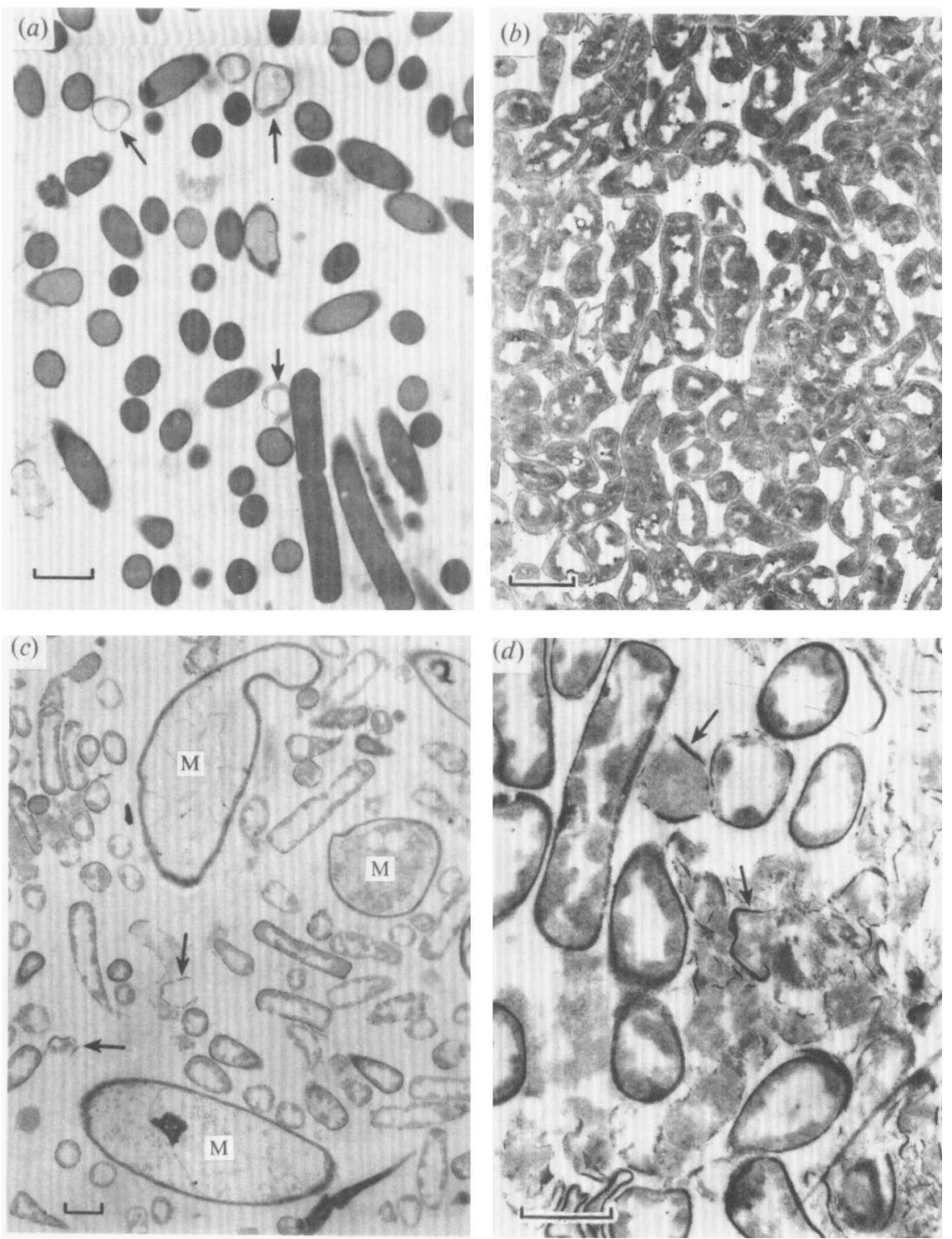

Fig. 2. Growth of $A$. bisporus on $B$. subtilis (asporogenous). (a) B. subtilis cells cultured in Spizizen salts medium to the late-exponential phase; arrows indicate lysed cells. (b) Cells cultured as in $(a)$, killed in trichloroacetic acid then thoroughly washed in distilled water and extracted with ether before being freeze-dried. $(c, d)$ Cells treated as in (b) suspended in liquid medium and degraded by $A$. bisporus (M) during $35 \mathrm{~d}$ growth; arrows indicate cell wall fragments. The bar markers represent $1 \mu \mathrm{m}$.

purified by Hash (1963), which lysed Gram-positive bacteria only. Furthermore, Hash did not indicate that the lytic ability of Chalaropsis sp. played any part in the nutrition of the fungus. Many of the Basidiomycetes screened here probably produced proteases and possibly also extracellular enzymes capable of hydrolysing the peptidoglycans of bacterial walls (Table 2). Some Ascomycetes, Fungi Imperfecti and Phycomycetes were also able to degrade dead $B$. subtilis, but it would seem that the slower growing Basidiomycetes are more suited to this mode of nutrition. The morphology of Basdiomycetes, compared with that on standard fungal 


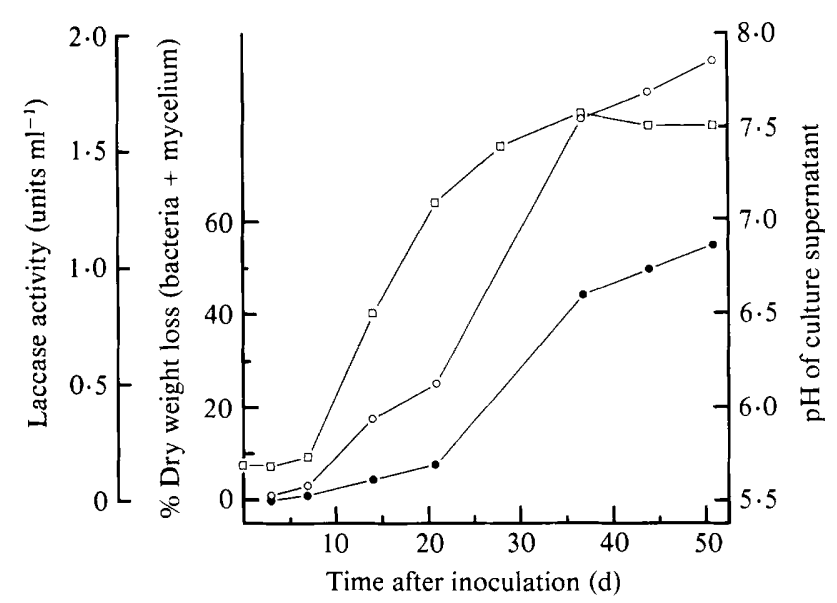

Fig. 3. Changes in laccase activity (O), dry weight $(O)$ and $\mathrm{pH}(\square)$ during growth of $A$. bisporus on killed $B$. subtilis in liquid culture.

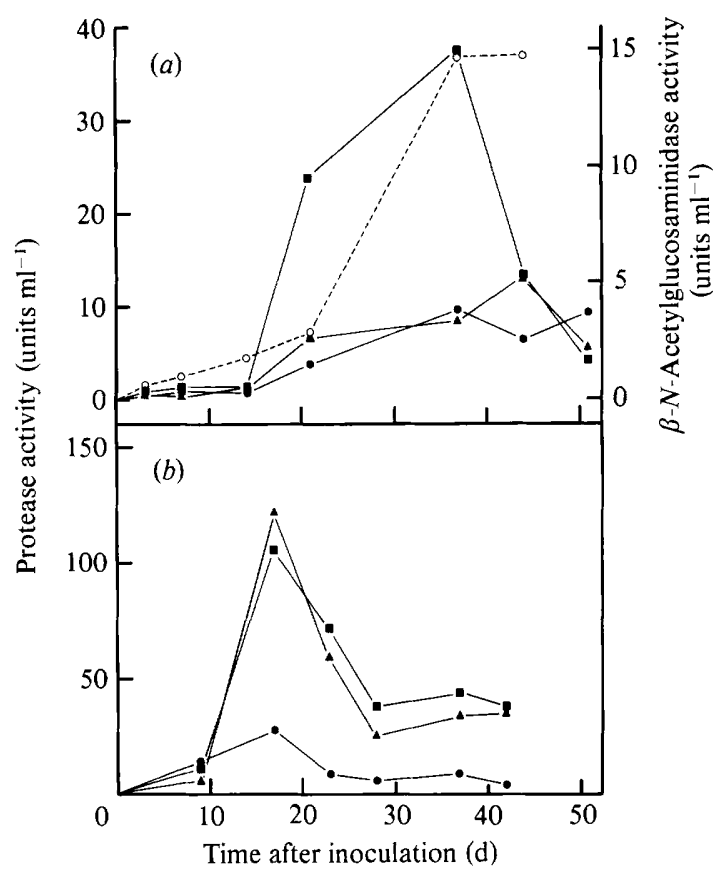

Fig. 4. (a) Protease and $\beta$ - $N$-acetylglucosaminidase activities of $A$. bisporus grown in Treschow basal salts medium containing killed $B$. subtilis as sole carbon and nitrogen source: $O$, acid protease $(\mathrm{pH} \mathrm{3.6)} \mathbf{\boldsymbol { \sigma }}$, neutral protease $(\mathrm{pH} 7.0) ; \boldsymbol{\Delta}$, alkaline protease $(\mathrm{pH} \mathrm{9.1);O}, \beta$ - $N$-acetylglucosaminidase $(\mathrm{pH} 5 \cdot 0)$.

(b) Protease activities of $A$. bisporus grown in Treschow basal salts medium containing insoluble casein (BDH; $100 \mathrm{~g}^{-1}$ ) as sole carbon and nitrogen source; $\mathbf{O}$, acid protease (pH 3.6$) ; \mathbf{\square}$, neutral protease $(\mathrm{pH} \mathrm{7.0)} ; \boldsymbol{\Delta}$, alkaline protease $(\mathrm{pH} 9 \cdot 1) . \beta$-N-Acetylglucosaminidase was not assayed in this medium.

media, was relatively unaltered, although mycelial extension rates were almost halved, whereas Fungi Imperfecti such as Aspergillus, Penicillium and Trichoderma, all renowned for the production of a wide range of extracellular hydrolytic enzymes, showed severely restricted, atypical growth. 
Table 3. Extracellular enzymes assayed in the culture supernatants of A. bisporus growing on killed B. subtilis in Treschow basal salts medium

\begin{tabular}{|c|c|c|c|c|}
\hline Enzyme & EC number & Possible substrate & $\begin{array}{l}\text { Presence/ } \\
\text { absence }\end{array}$ & Activity after $40 \mathrm{~d}$ \\
\hline Lysozyme & 3.2 .1 .17 & Cell wall & - & - \\
\hline Laccase & 1.10 .3 .2 & (Growth marker) & + & 1.75 laccase units $\mathrm{ml}^{-1}$ \\
\hline Lipase & 3.1 .1 .3 & Lipids & + & Not determined \\
\hline$\beta$-N-Acetyl-D-glucosaminidase & 3.2 .1 .30 & Cell wall & + & $15.0 \mu \mathrm{mol}$ nitrophenol $\mathrm{min}^{-1} \mathrm{ml}^{-1}$ \\
\hline DNAase & 3.1 .21 .1 & DNA & -* & - \\
\hline RNAase & 3.1 .27 .5 & RNA & $-^{*}$ & - \\
\hline Acid protease (pH 3.6) & & Protein & + & $10 \cdot 0 \mu \mathrm{gBB} \mathrm{h}^{-1} \mathrm{ml}^{-1}$ \\
\hline Neutral protease $(\mathrm{pH} 7.0)$ & & Protein & + & $37.0 \mu \mathrm{g} \mathrm{RBB} \mathrm{h}^{-1} \mathrm{ml}^{-1}$ \\
\hline Alkaline protease ( $\mathrm{pH} 9.1)$ & & Protein & + & $13 \cdot 0 \mu \mathrm{g} \mathrm{RBB} \mathrm{h}^{-1} \mathrm{ml}^{-1}$ \\
\hline Tyrosinase & 1.14 .18 .1 & & - & - \\
\hline
\end{tabular}

* DNAase and RNAase were detected in the supernatants of cultures grown in phosphate-free medium.

In the experiments using $B$. subtilis in liquid cultures it is important to emphasize that the cells were killed, washed and extracted with ether to inactivate endogenous autolysins and to remove the soluble cell contents which would provide an easily assimilated source of nutrition for the fungal mycelium. Thus, the growth observed for $A$. bisporus and other fungi must have been due to the degradation of insoluble polymers.

There did appear to be some material attached to the surface of the bacterial walls; conceivably this was cytoplasmic material released from the cells as a result of their distortion during freeze-drying, and subsequently precipitated and made visible by fixation (Fig. $2 b$ ). The mode of attack of the lytic enzymes of $A$. bisporus on $B$. subtilis walls parallels the findings of Burdett (1980) who investigated sites of autolysis in B. subtilis. Burdett found that most of the autolysin was located at the cross-wall, and following dissolution of the septum, the cylindrical wall was subject to autolysis. Degradation of the bacterial walls in this present study and that of Burdett appeared to occur not by a process of continuous thinning, but by an increase in the size of gaps in the wall and by an increase in the size of holes that were made (Fig. $2 c$ ). The remaining portions of the wall remained at a relatively constant thickness (Fig. $2 d$ ).

The extracellular enzymes of $A$. bisporus assayed so far could account for degradation of the bacterial wall polymers and intracellular proteins, lipids and nucleic acids. This fungus has been found to produce an inducible $\beta$ - $N$-acetylglucosaminidase but no muramidase; the former enzyme might be significant in peptidoglycan degradation. No tyrosinase activity was found in the culture supernatants showing that all the enzymes assayed were extracellular and not released by autolysis of $A$. bisporus mycelium. Burdett (1980) noted that whatever the specificity of a lysin the morphological sequence of lysis was much the same. For example, $B$. subtilis (with an amidase and glucosaminidase) seemed to be lysed in the same manner as Lactobacillus (muramidase). It is likely that $A$. bisporus produces other enzymes capable of degrading bacteria but these have not yet been sought.

The efficiency of conversion of dead bacteria to fungal mycelium and $\mathrm{CO}_{2}$ was difficult to assess accurately because the mycelium was intimately bound to the bacterial cells on which it was growing and could not be physically separated. However, total dry weight loss in the liquid cultures was $50 \%$ in $50 \mathrm{~d}$ (Fig. 3), and since a large part of the remaining dry weight consisted of fungal mycelium, the bulk of bacterial biomass had evidently been degraded. Bacterial degradation may, indeed, have been retarded by the clumping of the freeze-dried bacteria used in these experiments.

Wood (1979) found that growth of A. bisporus mycelium in liquid cultures was directly proportional to the quantity of extracellular laccase. Thus, the amount of laccase produced in the liquid medium containing bacteria was adopted here as an indication of mycelial growth, 
and was found to parallel dry weight loss in the cultures (Fig. 3). The culture pH showed a large shift from acid to alkaline, the cause of which has yet to be determined, but it may have been due to the release of amino groups. The progressive browning of the liquid cultures was probably due to the production of polyphenols by the mushroom mycelium.

These experiments have shown that $A$. bisporus is able to degrade dead bacteria and utilize them as a sole source of both carbon and nitrogen. Bacterial cells may also be capable of acting as sole source of phosphorus, but no nucleases were detected in the standard cultures (Table 3) presumably because the medium had a high phosphate level due to the buffer used. However, DNAase and RNAase activities were detected in cultures containing bacteria as the sole phosphate source. The ability of $A$. bisporus to lyse and degrade live bacteria is at present being determined. Degradation of living or dead bacteria may be a significant mode of nutrition for fungi growing in certain ecological niches, such as leaf litter or other habitats where both bacteria and filamentous fungi are found in quantity. It is noteworthy that slime moulds actively feed on bacteria and they occupy a similar habitat to litter-degrading Basidiomycetes.

We are indebted to Steve Matcham, Peter Atkey and John Pegler for assistance with electron microscopy, and to Sarah Molyneux for technical assistance. We are grateful to Dr Don Grant (Cawthron Institute, Nelson, New Zealand) and Dr D. M. Spencer for their constructive discussion of the manuscript. Dr I. D. J. Burdett (National Institute for Medical Research, London) is thanked for sending a draft copy of his paper prior to publication. Ken Baker (ARC Unit of Nitrogen Fixation, University of Sussex) generously provided assistance and facilities for the bulk production of $B$. subtilis.

\section{REFERENCES}

BurdetT, I. D. J. (1980). Analysis of sites of autolysis in Bacillus subtilis by electron microscopy. Journal of General Microbiology 120, 35-49.

Demetriou, J. A., Drewes, P. A. \& Gin, J. B. (1974). Lysozyme (muramidase). In Clinical Chemistry, Principles and Technics, 2nd edn, pp. 949-952. Edited by R. J. Henry, D. C. Cannon \& J. W. Winkleman. Hagerstown, Maryland, U.S.A.: Harper and Row.

DOMSCH, K. H., BeCK, Th., ANDERSON, J. P. E, Söderström, B., Parkinson, D. \& Trolldenier, G. (1979). A comparison of methods for soil microbial population and biomass studies. Zeitschrift für Pflanzenernährung und Bodenkunde 142, 520-533.

Eggins, H. O. W. \& Pugh, G. J. F. (1962). Isolation of cellulose-decomposing fungi from the soil. Nature, London 193, 94-95.

Fermor, T. R. \& WoOd, D. A. (1979). The microbiology and enzymology of wheat straw mushroom compost production. In Straw Decay and its Effect on Disposal and Utilization, pp. 105-112. Edited by E. Grossbard. Chichester: John Wiley.

Fermor, T. R. SMith, J. F. \& Spencer, D. M. (1979). The microflora of experimental mushroom composts. Journal of Horticultural Science 54, 137-147.

GoodAy, G. W. (1979). A survey of polysaccharase production: a search for phylogenetic implications. In Microbial Polysaccharides and Polysaccharases, pp. 437-460. Edited by R. C. W. Berkeley, G. W. Gooday \& D. C. Ellwood. London: Academic Press.

Hash, J. H. (1963). Purification and properties of staphylolytic enzymes from Chalaropsis $\mathrm{sp}$.
Archives of Biochemistry and Biophysics 102 , 379-388.

KARNovsky, M. J. (1965). A formaldehydeglutaraldehyde fixative of high osmolarity for use in electron microscopy. Journal of Cell Biology 27, 137A-138A.

Lawrence, R. C., Fryer, T. F. \& Reiter, B. (1967). A rapid method for the quantitative estimation of microbial lipases. Nature, London 213, 1264-1265.

Paul, E. A. \& Voroney, R. P. (1980). Nutrient and energy flows through the soil biomass. In Contemporary Microbial Ecology, pp. 215-238. Edited by D. C. Ellwood, J. N. Hedger, M. J. Latham, J. M. Lynch \& J. H. Slater. London: Academic Press.

Piggot, P. J. (1975). Characterization of a cym mutant of Bacillus subtilis. Journal of General Microbiology 89, 371-374.

REYNOLDS, E. S. (1963). The use of lead citrate at high $\mathrm{pH}$ as an electron-opaque stain in electron microscopy. Journal of Cell Biology 17, 208-212.

Rinderknect, H., Geokas, M. C., Silverman, P. \& HaverbacK, B. J. (1968). A new ultrasensitive method for the determination of proteolytic activity. Clinica chimica acta 21, 197-203.

Siala, A. H. \& Gray, T. R. G. (1974). Growth of Bacillus subtilis and spore germination in soil observed by a fluorescent antibody technique. Journal of General Microbiology 81, 191-198.

Sierra, G. (1957). A simple method for the detection of lipolytic activity of micro-organisms and some observations on the influence of the contact between cells and fatty substrates. Antonie van Leeuwenhoek 23, 15-22. 
SpurR, A. H. (1969). A low-viscosity epoxy resin embedding medium for electron microscopy. Journal of Ultrastructure Research 26, 31-43.

StolP, H. \& StaRr, M. P. (1965). Bacteriolysis. Annual Review of Microbiology 19, 79-104.

Strominger, J. L. \& Ghuysen, J. M. (1967). Mechanisms of enzymatic bacteriolysis. Science 156, 213-221.

Treschow, C. (1944). Nutrition of the cultivated mushroom. Dansk botanisk Arkiv 11, 1-180.
Wood, D. A. (1979). A method for estimating biomass of Agaricus bisporus in a solid substrate, composted wheat straw. Biotechnology Letters 1, 255-260.

Wood, D. A. \& Goodenough, P. W. (1977). Fruiting of Agaricus bisporus. Changes in extracellular enzyme activities during growth and fruiting. Archives of Microbiology 114, 161-165. 